\title{
Isolated thyroid metastasis from oesophageal primary- a rare clinical scenario
}

\author{
Suvendu Maji, Indranil Ghosh, Krishna Kumar Singh \\ Department of Surgical Oncology, Chittaranjan National Cancer Institute, \\ Kolkata, India.
}

Keywords: Thyroid metastases; oesophageal carcinoma; squamous cell carcinoma; dysphagia; oesophagus

\section{Introduction}

Oesophageal cancer is the second and fifth most common cancer among males and females respectively in India. Most of these cancers present at an advanced age and less than 10\% patients survive beyond 5 years after diagnosis [1,2]. Most of them present initially with dysphagia. Other symptoms include foreign body sensation in the throat, retrosternal pain, weight loss and cachexia. Presence of distant organ metastasis makes it a stage 4 disease according to the latest AJCC staging system. Synchronous occurrence of thyroid metastasis from oesophageal primary is an exceedingly uncommon scenario. Limited number of cases has been described in the English literature. The appropriate management in such group of patients remains unknown at this point of time.

\section{Case report}

A 65 years old lady presented to us with dysphagia to both solids and liquids for the last 10 months. She also complained of foreign body sensation in her throat. Epigastric pain, dyspepsia, nausea, vomiting and anorexia were absent. However she complained of losing few kilos of weight in the last 4 months. She had no other metastatic symptoms. Her past surgical and medical history was unremarkable. Her general survey was normal. On detailed physical examination a swelling was noticed in front of her neck which moved up with deglutition but did not move with protrusion of tongue (Figure.1).

On palpation the swelling was firm with ill defined margins. Rest of her physical and systemic examination was normal. A barium oesophagogram done showed a narrow irregular segment at the region of mid oesophagus (Figure.2). An upper gastro intestinal endoscopy showed presence of ulceroproliferative growth in the mid oesophagus. Biopsy

Correspondence: Suvendu Maji

E-mail: drsuvendumaji@rediffmail.com

Received: 03-03-2017 Accepted: 10-05-2017

(i) http://orchid.org/0000-0003-3815-7364 DOI: http://doi.org/10.4038/sljs.v35i2.8389

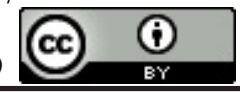

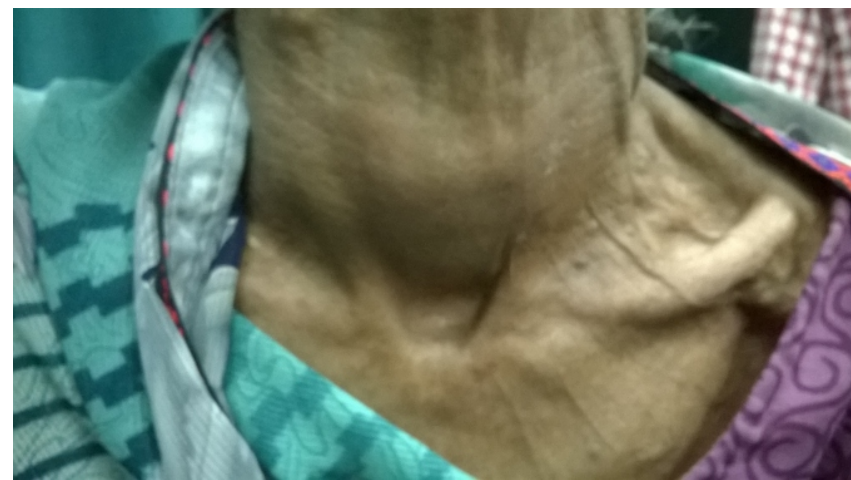

Figure 1. Showing a swelling in front of neck which moves up with deglutition.

was suggestive of moderately differentiated squamous cell carcinoma of the oesophagus. An ultrasonography neck showed presence of hypoechoic mass in the left lobe of thyroid with irregular margins. Fine needle aspiration cytology (FNAC) from the mass showed presence of atypical epithelial cells in cohesive clusters with pleomorphic nuclei and scanty cytoplasm. Overall picture was suggestive of poorly differentiated carcinoma consistent with metastatic cancer. Routine blood tests and thyroid function tests were normal.

A computed tomography scan of the chest showed presence of irregular thickening of the oesophagus without mediastinal involvement .Rest of the metastatic work up was negative. The patient was discussed in multidisciplinary tumour board

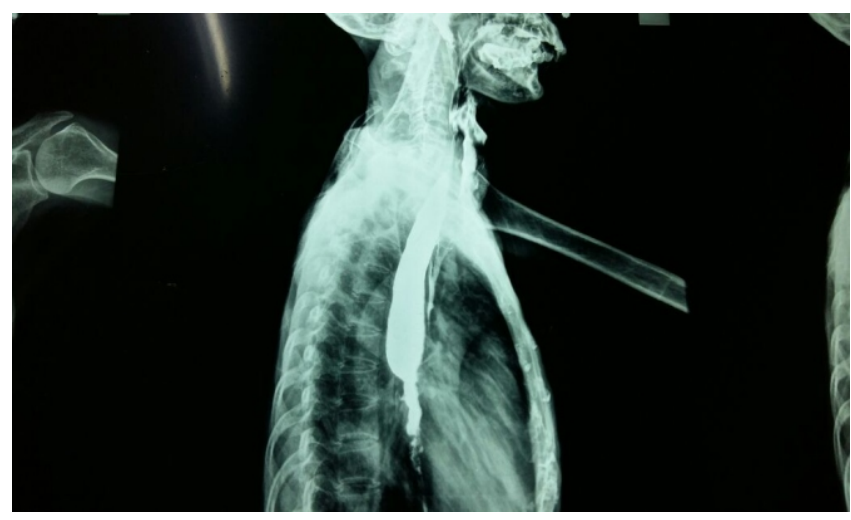

Figure 2. Barium esophagogram showing irregular filling defect in the mid esophagus. 


\begin{tabular}{|c|c|c|c|c|c|c|c|c|c|}
\hline $\begin{array}{l}\text { Cases } \\
\text { reported }\end{array}$ & Age/sex & $\begin{array}{l}\text { Chief } \\
\text { symptoms }\end{array}$ & USG + FNAC & $\begin{array}{l}\text { Barium } \\
\text { Esophagogram }\end{array}$ & $\begin{array}{l}\text { Upper G.I. } \\
\text { endoscopy }\end{array}$ & CT Thorax & $\begin{array}{l}\text { Primary site } \\
\text { of tumor }\end{array}$ & $\begin{array}{l}\text { Treatment } \\
\text { planned/received }\end{array}$ & Follow up \\
\hline $\begin{array}{l}\text { Basu } \\
\text { et al } 2005\end{array}$ & $\begin{array}{l}55 / \\
\text { Female }\end{array}$ & $\begin{array}{l}\text { Thyroid lump } \\
+ \text { dysphagia }\end{array}$ & $\begin{array}{l}\text { Locally advanced hypoechoic } \\
\text { mass with neck nodes + } \\
\text { Metastatic keratinizing SCC }\end{array}$ & $\begin{array}{l}\text { Mass in cervical } \\
\text { esophagus }\end{array}$ & $\mathrm{N} / \mathrm{A}$ & N/A & esophagus & $\begin{array}{l}\text { Details of surgery not } \\
\text { available. No details on } \\
\text { use of adjuvant therapy }\end{array}$ & N/A \\
\hline $\begin{array}{l}\text { Moullick } \\
\text { et al } 2012\end{array}$ & 61/Male & $\begin{array}{l}\text { Neck mass and } \\
\text { sterna lump }\end{array}$ & $\begin{array}{l}\text { Left lobe of thyroid enlarge+ } \\
\text { Metastatic SCC }\end{array}$ & N/A & $\begin{array}{l}\text { Mid } \\
\text { esophageal } \\
\text { growth }\end{array}$ & $\begin{array}{l}\text { Locally advanced } \\
\text { thyroid and sternal } \\
\text { mass }\end{array}$ & esophagus & $\begin{array}{l}\text { Planned for external } \\
\text { beam radiotherapy and } \\
\text { combination } \\
\text { chemotherapy }\end{array}$ & $\begin{array}{l}\text { Patient died } \\
\text { before receiving } \\
\text { any therapy }\end{array}$ \\
\hline $\begin{array}{l}\text { Gooptu } \\
\text { et al } 2013\end{array}$ & $\begin{array}{l}60 / \\
\text { Female }\end{array}$ & $\begin{array}{l}\text { Thyroid lump } \\
\text { with } \\
\text { dysphagia }\end{array}$ & $\begin{array}{l}\text { Left lobe nodule with neck } \\
\text { nodes+ Poorly differentiated } \\
\text { SCC }\end{array}$ & N/A & $\begin{array}{l}\text { Mid } \\
\text { esophageal } \\
\text { growth }\end{array}$ & N/A & esophagus & Chemoradiation & $\mathrm{N} / \mathrm{A}$ \\
\hline $\begin{array}{l}\text { Chen et al } \\
2014\end{array}$ & 61/Male & $\begin{array}{l}\text { Dyspnea, } \\
\text { dysphagia, } \\
\text { thyroid lump }\end{array}$ & $\begin{array}{l}\text { Left lobe mass with neck } \\
\text { nodes+ Diffuse infiltration of } \\
\text { atypical cells }\end{array}$ & N/A & $\begin{array}{l}\text { Distal } \\
\text { esophageal } \\
\text { growth }\end{array}$ & $\begin{array}{l}\text { Locally advanced } \\
\text { thyroid mass encasing } \\
\text { neck vessels }\end{array}$ & esophagus & $\begin{array}{l}\text { Palliative } \mathrm{B} / \mathrm{LTT}+ \\
\text { tracheostomy } \mathrm{f} / \mathrm{b} \\
\text { chemotherapy and } \\
\text { radiation therapy. }\end{array}$ & $\begin{array}{l}\text { Patient died after } \\
11 \text { months }\end{array}$ \\
\hline $\begin{array}{l}\text { Present } \\
\text { case } \\
2016\end{array}$ & $\begin{array}{l}65 / \\
\text { Female }\end{array}$ & dysphagia & $\begin{array}{l}\text { Hypoechoic mass in left lob e } \\
\text { of thyroid + Poorly } \\
\text { differentiated carcinoma }\end{array}$ & $\begin{array}{l}\text { Mid esophageal } \\
\text { growth }\end{array}$ & $\begin{array}{l}\text { Mid } \\
\text { esophageal } \\
\text { growth }\end{array}$ & $\begin{array}{l}\text { Thickening of the } \\
\text { midesophagus with } \\
\text { irregular growth }\end{array}$ & esophagus & $\begin{array}{l}\text { Planned for } 1^{\text {st }} \text { line } \\
\text { chemotherapy and } \\
\text { esophageal stenting }\end{array}$ & N/A \\
\hline
\end{tabular}

Table 1. Showing clinicopathologic characteristics of the published case reports.

* SCC - Squamous cell Carcinoma, TT - Total Thyroidectomy

where considering the stage of the disease and the good performance status of the patient a decision to start 1st line chemotherapy along with oesophageal stenting was taken. The option of palliative thyroidectomy was explained to the patient in the event of progression of the thyroid lump. However she did not turn up for the scheduled treatment and could not be traced further.

\section{Discussion}

The most common primary presenting with thyroid metastases is renal cell carcinoma [3]. Lung, breast, colon, melanoma are other primaries which can present similarly. The most common gastrointestinal primary to metastasize to the thyroid is colorectal. Thyroid metastasis from oesophageal squamous cell cancer is extremely rare and only 4 cases have been reported so far, out of which three have been reported from India. Primary SCC of the thyroid is a rarer entity which affects individuals of age group 50-60 years having history of long standing goitre. They are more common in abnormal thyroid glands. Most of them present with rapid enlargement of a long standing neck mass and are often locally advanced at presentation.

They are usually radio resistant and fatal. Prognosis tends to be poor with median survival less than 6 months. Metastatic thyroid cancer appears to be commoner. Secondary lesions of the thyroid are often solitary in nature although the more uncommon multifocal diffuse lesions have also been reported in literature [4].Most of these metastases occur either by direct extension from contiguous lesion or via haematogenous or lymphatic spread. Presence of any atypical histology in a thyroid lump should arouse suspicion of secondary metastatic deposits. FNAC can be a useful tool. Immunohistochemistry with common thyroid markers (like thyroid transcription factor 1,thyroglobulin etc) can further help in making right diagnosis $[4,5]$. On review of English literature we found 4 cases of squamous cell carcinoma oesophageal carcinoma with thyroid metastasis, published in the last 10 years. Chen et al5 in 2014 in their review literature presented 9 similar cases with thyroid metastasis.

It is interesting to note that although the mode of presentation and arriving at final diagnosis was more or less similar in all those cases, there was striking heterogeneity in the way they were treated and their reported outcomes. All the four cases were managed differently. Presence of synchronous thyroid metastases from oesophageal primary is extremely rare. In absence of any treatment guidelines such patients are perhaps best dealt in higher specialty centres with facilities for multimodal therapy.

\section{Conclusion}

Presence of asymptomatic thyroid metastasis in a case of primary oesophageal squamous cell carcinoma is an unusual scenario. High index of suspicion should be maintained to make right diagnosis. Due to paucity of such cases no treatment recommendations exist at present. Hence we strongly suggest reporting of such cases. Treatment of such patients should be individualized and requires multidisciplinary tumour board for optimum treatment selection.

\section{References}

1. Kapoor A, Kumar V, Singhal MK, Nirban RK, Beniwal SK, Kumar HS. Sociodemographic Parameters of Esophageal Cancer in Northwest India: A Regional Cancer Center Experience of 10 Years. Indian Journal of Community Medicine : Official Publication of Indian Association of Preventive \& Social Medicine. 2015;40(4):264-267. doi:10.4103/0970-0218.164399.

2. Parkin DM, Bray F, Ferlay J, Pisani P. Global cancer statistics. 2002,CA Cancer J Clin.2005;55:74-108. doi:10.3322/canjclin.55.2.74[PubMed]

3. Basu S, Nair N, Borges A M. Squamous cellcarcinoma of eso- 
phagus masquerading as solitary thyroid nodule. Indian Journal Of Cancer 2005 Oct-Dec;42 (4):205-7.

4. Gooptu S, Sharma S, Singh G, Ali I. Uncommon metastasis to thyroid gland presenting as a thyroid nodule. International Journal of Case Reports and Images 2013;4(11):615-618. doi:10.5348/ijcri-2013-11-393-CR-7
5. Chen et al.: Metastasis of distal esophageal carcinoma to the thyroid with presentation simulating primary thyroidcarcino-ma: a case report and review of the literature. World Journal of

Surgical Oncology 2014 12:106.

doi.org/10.1186/1477-7819-12-106

\footnotetext{
Key Points

- All neck masses should prompt detailed investigation with the clinical history in mind

- High index of suspicion should be maintained for diagnosis

- Treatment of such unusual cases needs multidisciplinary board discussions and often multimodality therapy hence should be referred to higher tertiary referral centers.
}

\section{Answers for images in surgery (from page 21)}

1) Brodie abscess (BA)

X-rays show a well demarcated area of destructed bone surrounded by a thick rim of reactive sclerosis in cancellous tissue near the end of upper tibia. With the history of compound fracture, osteomyelitis should be suspected.

Sir Benjamin Brodie first described subacute osteomyelitis in 1832 [5]. Ever since, sub-acute osteomyelitis of the bone in the form of pyogenic abscess were named after him as Brodie abscesses.

Most of the patients present with localized pain, often nocturnal, alleviated by simple analgesics [2, 3, 4]. It often mimics the symptoms of osteoid osteoma [7]. BA has a predilection to tubular bones like tibia, fibula, femur and radius. It particularly affects the metaphyses of these bones, most commonly the distal and proximal ends of tibia [1]. However it may rarely traverse the metaphysic of tubular bones into epiphyses and diaphysis. BA is a diagnostic challenge because in the acute phase the clinical features are minimal and non-specific. The initial infection is localized to a small area and is confined by a thick rim of inflammatory fibrous tissue forming an abscess causing bone destruction.

Due to its diagnostic challenges, various imaging modalities are used to confirm the diagnosis. In the plain radiograph it usually appears as an oval lytic lesion. It may show a finger-like radiolucent tortuous channel extending towards the epiphyseal plate, which, when present, is pathognomonic. If a sequestrum is present, it may mimick an osteoid osteoma.

2) The differential diagnosis for radiological appearance of Brodie abscess include
I. Osteoid osteoma
II. Non-ossifying fibroma
III. Giant cell tumor
IV. Eosinophilic granuloma
V. Chondroblastoma
VI. Fibrous dysplasia

3) Isotope bone scan-BA typically enhances on the delayed. CT- It demonstrates a central hypodense cystic lesion with a sclerotic margin due to an extensive fibrous periosteal reaction. 